\title{
DAYA PREDASI IKAN CUPANG (Betta splendens) DAN IKAN PLATI PEDANG (Xyphophorus Helleri) TERHADAP LARVA NYAMUK Aedes aegypti
}

Fathul Alim, Winarko, Ernita Sari

Jurusan Kesehatan Lingkungan Poltekkes Kemenkes Surabaya

Email: al.coverboyrlc@gmail.com

\begin{abstract}
ABSTRAK
Ikan cupang juga diketahui merupakan salah satu ikan predator jentik nyamuk. Ikan plati pedang termasuk ikan omnivora termasuk menyukai jentik nyamuk, tetapi lebih cenderung menyukai tumbuh-tumbuhan. Penelitian ini bertujuan untuk mengetahui perbedaan daya predasi ikan cupang (Betta sp.) dan ikan plati pedang (xyphophorus Helleri) terhadap larva nyamuk Aedes aegypti.

Jenis penelitian ini adalah eksperimen murni dengan desain one shoot case study. Subyek penelitian adalah larva nyamuk Aedes aegypti instar III, ikan cupang dan plati pedang masing-masing replikasi sebanyak 16 kali. Setiap waktu pengamatan menggunakan larva instar III sebanyak 25 ekor. Pengamatan dilakukan selama 1 jam. Analisis data menggunakan independent samples test. Kriteria uji Independent Samples Test : jika nilai $p$ value 0.000 , membuktikan adanya perbedaan yang bermakna antara daya predator ikan cupang (Betta sp.) dengan ikan plati pedang (xyphophorus Helleri) terhadap larva nyamuk Aedes aegypti dan sebaliknya.

Hasil penelitian menunjukan bahwa daya predasi ikan cupang dan plati pedang dalam waktu 1 jam sudah habis memangsa semua larva jentik dengan persentase $100 \%$, sehingga dapat disimpulkan bahwa ikan Cupang dan ikan Plati Pedang selama kurun waktu 1 jam mampu memangsa larva Aedes aegypti 100\%

Disarankan kepada Dinas Kesehatan dan masyarakat menggunakan ikan Plati Pedang sebagai pemberantasan Vektor Aedes aegypti secara biologis melalui larvanya dan bagi penelitian lain perlu dilakukan penelitian lebih lanjut untuk mengetahu kecepatan daya predasi.
\end{abstract}

Kata Kunci: daya predasi ikan cupang (Betta sp.), ikan plati pedang (xyphophorus Helleri), larva nyamuk Aedes aegypti.

\section{PENDAHULUAN}

Penyakit Demam Berdarah Dengue (DBD) masih merupakan salah satu masalah kesehatan masyarakat yang utama di Indonesia. Jumlah penderita dan luas daerah penyebarannya semakin bertambah seiring dengan meningkatnya penyakit mobilitas dan kepadatan penduduk. Demam berdarah adalah demam akut yang disebabkan oleh virus dengue, yang masuk ke peredaran darah manusia melalui gigitan nyamuk dari genus Aedes, misalnya Aedes aegypti atau Aedes albopictus. Aedes aegypti adalah vektor yang paling banyak ditemukan menyebabkan penyakit ini. Nyamuk dapat membawa virus dengue setelah menghisap darah orang yang telah terinfeksi virus tersebut. Sesudah masa inkubasi virus di dalam nyamuk selama 8-10 hari, nyamuk yang terinfeksi dapat mentransmisikan virus dengue tersebut ke manusia sehat yang digigitnya (Depkes, 2011).

Berdasarkan hasil data Angka Bebas Jentik ( $A B J)$ Kota Surabaya yang didapatkan dari Dinas Kesehatan Kota Surabaya, 2019 ialah 85,77\% pada tahun $2012,89,77 \%$ pada tahun $2013,85,74 \%$ pada tahun 2014, 88,68\% pada tahun $2015,89,50 \%$ pada tahun $2016,91,93 \%$ pada tahun 2017 dan 93,73\% pada tahun 2019. Sehingga dapat disimpulkan bahwa data $A B J$ Kota Surabaya terendah terjadi 
pada tahun 2014 dan data ABJ Kota Surabaya Tertinggi terjadi pada tahun 2018.

Menurut penelitian Utama (2010) upaya pengendalian demam berdarah secara biologi salah satunya dengan memelihara ikan. Pemanfaatan ikan dalam upaya pengendalian demam berdarah efektif dilakukan pada stadium larva, terutama larva instar III karena pada stadium ini larva mudah diidentifikasi dengan ciri adanya rambut pada seluruh tubuh, kepala tampak menghitam, tingkat metabolisme yang belum matur serta pergerakan yang lebih banyak.

Berdasarkan hasil pengamatan uji coba ikan cupang dan ikan plati pedang yang telah didapatkan mampu memangsa lebih dari 10 ekor larva jentik instar III nyamuk Aedes aegypti dalam waktu sehari.Pemanfaatan ikan sebagai predator alami larva nyamuk adalah salah satu cara pengendalian secara biologi yang mudah untuk dilakukan oleh masyarakat. Metode pengendalian secara biologis ini dapat mengurangi kepadatan larva nyamuk serta tidak menimbulkan masalah bagi kesehatan lingkungan (Depkes, 2010). Berdasarkan beberapa hasil penelitian yang telah dilakukan, ikan menunjukkan kemampuan yang berbeda dalam mengendalikan larva nyamuk.

\section{METODE PENELITIAN}

Jenis penelitian ini adalah Eksperimen, yaitu penelitian yang memberkan perlakuan (eksperimen) Rancangan penelitian ini menggunakan desain One shoot case study (studi kasus satu tembakan) digunakan untuk mengetahui nilai ilmiah dalam suatu pengukuran dalam penelitian eksperimen. Dimana dalam desain ini, ada satu kelompok yang diberi umpan perlakuan yang kemudian hasil dari perlakuan tersebut diobservasi, Perlakuan dalam hal ini merupakan variabel bebas dan hasilnya adalah variabel terikat. Penelitian ini termasuk jenis penelitian fenomenologi bersifat komparatif. Menurut
Sastroasmoro \& Ismale (2011) penelitian komparatif adalah jenis penelitian untuk mengetahui perbedaan dari fenomena tertentu.

Variabel Terikat Dalam penelitian ini variable terikat digunakan pada daya predasi ikan adalah larva nyamuk Aedes aegypti. Variabel Bebas Dalam penelitian ini variable bebas adalah ikan cupang dan ikan plati pedang sebagai upaya pengendalian vector demam berdarah dengue (DBD).

Teknik Pengumpulan data

a. Tahap Persiapan

1) Wadah akuarium untuk menampung air yang nantinya digunakan untuk menempatkan obyek penelitian.

2) Telur larva instar III nyamuk Aedes aegypti sebanyak 800 ekor.

b. Penyediaan Larva Aedes aegypti

1) Telur nyamuk Aedes aegypti didapatkan dari kampus Poltekkes Kemenkes Surabaya

2) Telur nyamuk dipelihara sampai menetas menjadi larva

3) Larva kemudian dikelompokkan sesuai kebutuhan, yaitu jumlah masing-masing perlakuan 25 ekor dengan pengamatan 1 kali.

c. Langkah Pengumpulan Data

Langkah pengumpulan data dalam penelitian ini adalah;

1) Disiapkan 32 akuarium, masingmasing diisi air dengan volume $1500 \mathrm{ml}$.

2) Dari 32 akuarium diisi 25 larva tanpa diberi makan, 16 toples diisi ikan plati pedang dan 16 toples ikan cupang.

3) Pengamatan dilakukan pada 1 jam, kemudian dihitung jumlah larva yang dimakan ikan predator. 
Analisis data dilakukan setelah hasil uji normalitas menunjukkan data berdistribusi normal. Analisis data untuk menguji perbedaan daya predasi secara statistik menggunakan uji beda dua mean independent dengan uji independent samples test menggunakan program SPSS for windows dengan criteria pengujian sebagai berikut:

Ho diterima bila nilai $p>0,05$, berarti tidak ada perbedaan daya predasi antara ikan cupang dengan ikan plati pedang.

Ho ditotak bila nilai $p \leq 0,05$, berarti ada perbedaan daya antara ikan cupang dengan ikan plati pedang.

\section{HASIL DAN PEMBAHASAN}

\section{Distribusi Kematian Larva pada Ikan}

\section{Cupang (Betta sp)}

Berdasarkan hasil pengamatan daya predasi ikan cupang dalam waktu 1 jam sudah habis memangsa semua larva jentik yang diberikan, sehingga dapat disimpulkan bahwa daya predasi ikan Cupang $100 \%$ dalam memangsa larva Aedes aegypti. Pada saat dilakukan pengamatan, ternyata pada menit ke 6 (enam) semua larva sudah habis dimangsa oleh ikan Cupang.

\section{Distribusi Kematian Larva pada Ikan Plati Pedang (Xyphophorus Helleri)}

Daya predasi ikan Plati Pedang dalam waktu 1 jam sudah habis memangsa semua larva jentik, sehingga dapat disimpulkan bahwa daya predasi ikan Plati Pedang $100 \%$ dalam memangsa larva Aedes aegypti. Pada saat dilakukan. Pengamatan, ternyata pada menit ke 4 (empat) semua larva sudah habis dimangsa oleh ikan Plati Pedang.

\section{Perbedaan Daya Predasi Ikan Cupang (Betta sp.) dan Ikan Plati Pedang (Xyphophorus Helleri) sebagai predator Larva Nyamuk Aedes aegypti Secara diskriptif dapat dijelaskan bahwa daya predassi ikan cupang dengan ikan plati pedang sama memiliki daya predasi}

$100 \%$ terhadap larva Aedes aegypti yang dugunakan sebagai umpan, sehingga dapat disimpulkan tidak ada perbedaan dalam memangsa larva Aedes aegypti. Berdasarkan waktu yang digunakan ikan untuk memangsa habis larva Aedes aegypti, dapat disimpulkan bahwa ikan plati lebih cepat dalam menghabiskan umpan yang diberikan.

Berdasarkan analisis secara statistik yang didahului dengan dengan uji normalitas mendapatkan hasil bahwa ikan cupang dan ikan plati pedang sama-sama berdistribusi normal karena sama-sama $100 \%$ dalam menghabiskan umpan/mangsa larva nyamuk Aedes aegypti. Sedangkan hasil uji statistik mendapatkan kesimpulan bahwa daya predasi dari ke 16 ikan cupang dan 16 ikan plati pedang sama-sama memiliki rata-rata yang sama yaitu ikan cupang memiliki ratarata 25,00 dan ikan plati pedang memiliki rata-rata 25,00 sehingga $100 \%$ menghabiskan umpan/memangsa larva nyamuk Aedes aegypti dapat diartikan bahwa daya predasi ikan cupang dan ikan plati pedang sama-sama efektif dalam memangsa larva nyamuk Aedes aegypti.

\section{KESIMPULAN}

Tidak ada perbedaan antara daya predator ikan plati pedang (Xyphophorus Helleri) dan ikan cupang (Betta $s p$.) terhadap larva instar III nyamuk Aedes aegypti.

\section{SARAN}

Bagi instansi kesehatan dapat menggerakkan masyarakat melalui edukasi untuk menggunakan ikan sebagai PSN alami. Masyarakat dapat memperhatikan kegiatan PSN secara mandiri dan lebih teratur serta memanfaatkan ikan sebagai pemangsa larva nyamuk 


\section{DAFTAR PUSTAKA}

Depkes RI. 2010. Perilaku Hidup Nyamuk Aedes aegypti Sangat Penting Diketahui Dalam Melakukan Kegiatan Pemberantasan Sarang Nyamuk Termasuk Pemantauan Jentik Berkala. Dirjen PPM. Jakarta.

Depkes RI. 2011. Modul Pengendalian Demam Berdarah Dengue. Diakses 21 Pebruari 2015. http://pppl.depkes.go.id/.pdf

Sastroasmoro \& Ismael. 2011. Dasar Metodologi Penelitian Klinis. Sagung Seto: Jakarta

Utama, C. 2010. Tingkat Predasi Ikan Mujair (Oreochromis mossaambicus) Terhadap Larva Nyamuk Aedes aegypti. Diakses 21 Pebruari 2015. 